\title{
The Iron-Age of Storage Batteries: \\ Techno-Economic Promises and Challenges
}

Shashank Sripad, Dilip Krishnamurthy, and Venkatasubramanian Viswanathan*

Department of Mechanical Engineering, Carnegie Mellon University, Pittsburgh, Pennsylvania 15213

E-mail: venkvis@cmu.edu 
Rechargeable batteries are playing a crucial role in the transition to sustainable transportation and power generation, and this role is expected to become larger as we continue to make progress in mitigating anthropogenic climate change. ${ }^{1}$ Among the various performance metrics of rechargeable batteries, the salient ones include energy and power per unit weight (specific energy and power) and volume (energy and power density), unit cost, lifetime, and round-trip efficiency. ${ }^{2}$ While energy and power performance along with cost is more important for mobile applications, units costs, round-trip efficiency, and lifetime are more important for stationary applications. One of the most important metrics irrespective of the application is cost, which serves as a threshold for the adoption of rechargeable batteries, and has led battery researchers to find cheaper and more abundant raw materials while being cognizant of the trade-offs that come with it.

There have been two noteworthy developments in the battery industry in the first two quarters of 2021, (i) announcements by Volkwagen $A G$ and Tesla Inc. of their intention to employ lithium-iron-phosphate (LFP) for a large fraction of the anticipated production, ${ }^{3}$ (ii) announcement by stationary storage battery manufacturer Form Energy Inc. of the development of iron-air batteries for long-duration energy storage. ${ }^{4,5}$ The 2010 s saw nickel, cobalt, and manganese-based layered oxides gain more traction for transportation-based applications owing to their superior specific energy and energy density, ${ }^{6}$ however, in the early 2020 s the transportation industry is signaling a large scale shift to LFP as the cathode material of choice for mass-market applications, given the cost and availability despite the known compromise in performance. While the cost and performance of LFP has been extensively analyzed, ${ }^{7}$ similar analyses are unavailable for iron-air batteries, especially for grid storage and long-duration storage applications. In this article, we explore the techno-economic promises and challenges related to iron electrode systems, specifically in the iron-air system. We study the discharge-charge products of an iron-air system in an aqueous electrolyte using an iron-water Pourbaix diagram. Using the discharge-charge products from the Pourbaix analysis, we construct a proposed baseline iron-air cell to estimate the basic voltage and 
capacity of the cell. This cell is then assembled into a battery pack to analyze the unit cost of a 150-hour iron-air system using a process-based cost model developed from the BatPaC model. ${ }^{8,9}$ We estimate the cost of an iron-air battery pack system to be around US $\$ 25 / \mathrm{kWh}$ including the battery pack integration and the air delivery system costs. The cell materials cost account for about $20 \%$ of the total battery pack cost while the manufacturing, hardware, and gas delivery system make up the rest of the costs. We find that there is considerable room for engineering improvements which can drive the costs lower.

Iron-water Pourbaix diagram: To understand the chemical transformations of the iron electrode in the alkaline environment, it is crucial to derive the electrochemical phase diagram, typically referred to as the Pourbaix diagram in this context. The Pourbaix diagram represents the stable phases, which are associated with the minimum free energies, among the possible thermodynamically accessible phases at a given potential $U$ and $p H$.

The competing reaction involves hydrogen evolution reaction (HER), given by:

$\mathrm{H}_{2} \longleftrightarrow \mathrm{H}^{+}+2 \mathrm{e}^{-}$Reactions involving an equal number of protons (or hydroxide ions) and electrons will have a slope of $59 \mathrm{mV} / \mathrm{pH}$ unit in a Pourbaix diagram. ${ }^{10,11}$

Next, we list down reactions involving dissolution of the iron electrode, leading to solution species:

$\mathrm{Fe} \longleftrightarrow \mathrm{Fe}^{2+}+2 \mathrm{e}^{-}$ $\mathrm{Fe}^{2+} \longleftrightarrow \mathrm{Fe}^{3+}+\mathrm{e}^{-}$ The dissolution reactions listed above are $\mathrm{pH}$ independent and are horizontal lines in a Pourbaix diagram (potential on the vertical axis). In acidic conditions, the dissolved species are energetically favorable and dominate the Pourbaix diagram, as will be discussed later.

Next, we consider the possible solid-phase oxidation products, which could include stable hydroxides, oxides and oxyhydroxides. Iron forms numerous oxide and hydroxide phases, given its propensity to exist in both +2 and +3 oxidation states, and a mixture of +2 and +3 oxidation states. The stable compounds in the +2 oxidation state include: $\mathrm{Fe}(\mathrm{OH})_{2}, \mathrm{FeO}$, 
$\mathrm{FeO}_{2}$ (iron peroxide); +3 oxidation state include: $\mathrm{Fe}_{2} \mathrm{O}_{3}$ polymorphs, ${ }^{12} \mathrm{Fe}(\mathrm{OH})_{3}, \mathrm{FeOOH}$ polymorphs and mixed +2 and +3 compounds, which include: $\mathrm{Fe}_{3} \mathrm{O}_{4}$, etc. The slopes of equilibrium lines in the Pourbaix diagram, as shown in Figure 1, depend on the ratio of protons to electrons transferred. The associated reactions are given by:

$\mathrm{Fe}+2 \mathrm{H}_{2} \mathrm{O} \longleftrightarrow \mathrm{Fe}(\mathrm{OH})_{2}+2 \mathrm{H}^{+}+2 \mathrm{e}^{-}$

$\mathrm{Fe}(\mathrm{OH})_{2}+2 \mathrm{H}_{2} \mathrm{O} \longleftrightarrow 2 \mathrm{Fe}(\mathrm{OH})_{3}+2 \mathrm{H}^{+}$

$3 \mathrm{Fe}(\mathrm{OH})_{2}+2 \mathrm{OH}^{-} \longleftrightarrow \mathrm{Fe}_{3} \mathrm{O}_{4}+4 \mathrm{H}_{2} \mathrm{O}+2 \mathrm{e}^{-}$

$\mathrm{Fe}+\mathrm{H}_{2} \mathrm{O} \longleftrightarrow \mathrm{FeO}+2 \mathrm{H}^{+}+2 \mathrm{e}^{-}$

$3 \mathrm{FeO}+\mathrm{H}_{2} \mathrm{O} \longleftrightarrow \mathrm{Fe}_{3} \mathrm{O}_{4}+2 \mathrm{H}^{+}+2 \mathrm{e}^{-}$

$2 \mathrm{Fe}_{3} \mathrm{O}_{4}+\mathrm{H}_{2} \mathrm{O} \longleftrightarrow 3 \mathrm{Fe}_{2} \mathrm{O}_{3}+2 \mathrm{H}^{+}+2 \mathrm{e}^{-}$

In addition to the solid-phase oxidation productions, solution-phase oxidation products, such as $\mathrm{FeO}_{2}^{-}, \mathrm{HFeO}_{2}^{-}$, are also possible, given by:

$\mathrm{Fe}+2 \mathrm{H}_{2} \mathrm{O} \longleftrightarrow \mathrm{HFeO}_{2}^{-}+3 \mathrm{H}^{+}+2 \mathrm{e}^{-}$

$\mathrm{Fe}(\mathrm{OH})_{2} \longleftrightarrow \mathrm{HFeO}_{2}{ }^{-}+\mathrm{H}^{+}$

$\mathrm{HFeO}_{2}{ }^{-}+\mathrm{H}_{2} \mathrm{O} \longrightarrow \mathrm{Fe}(\mathrm{OH})_{3}+\mathrm{e}^{-}$

$\mathrm{Fe}(\mathrm{OH})_{3} \longrightarrow \mathrm{FeO}_{2}{ }^{-}+\mathrm{H}^{+}+\mathrm{H}_{2} \mathrm{O}$

$\mathrm{HFeO}_{2}{ }^{-} \longrightarrow \mathrm{FeO}_{2}{ }^{-}+\mathrm{H}^{+}+\mathrm{e}^{-}$

We anticipate the dissolution of chemical species such as $\mathrm{HFeO}_{2}{ }^{-}, \mathrm{FeO}_{2}{ }^{-}$, etc. to be associated with considerable kinetic barriers. The Pourbaix diagram is constructed using the tabulated thermodynamic values from the National Institute of Standards and Technology (NIST), and the solution phase free energies are calculated based on experimental equilibrium potentials. This avoids the well-known difficulties in calculating solution-phase free energies within Density Functional Theory (DFT). ${ }^{13}$

Examining the Pourbaix diagram constructed in Figure 1, the acidic region is dominated 

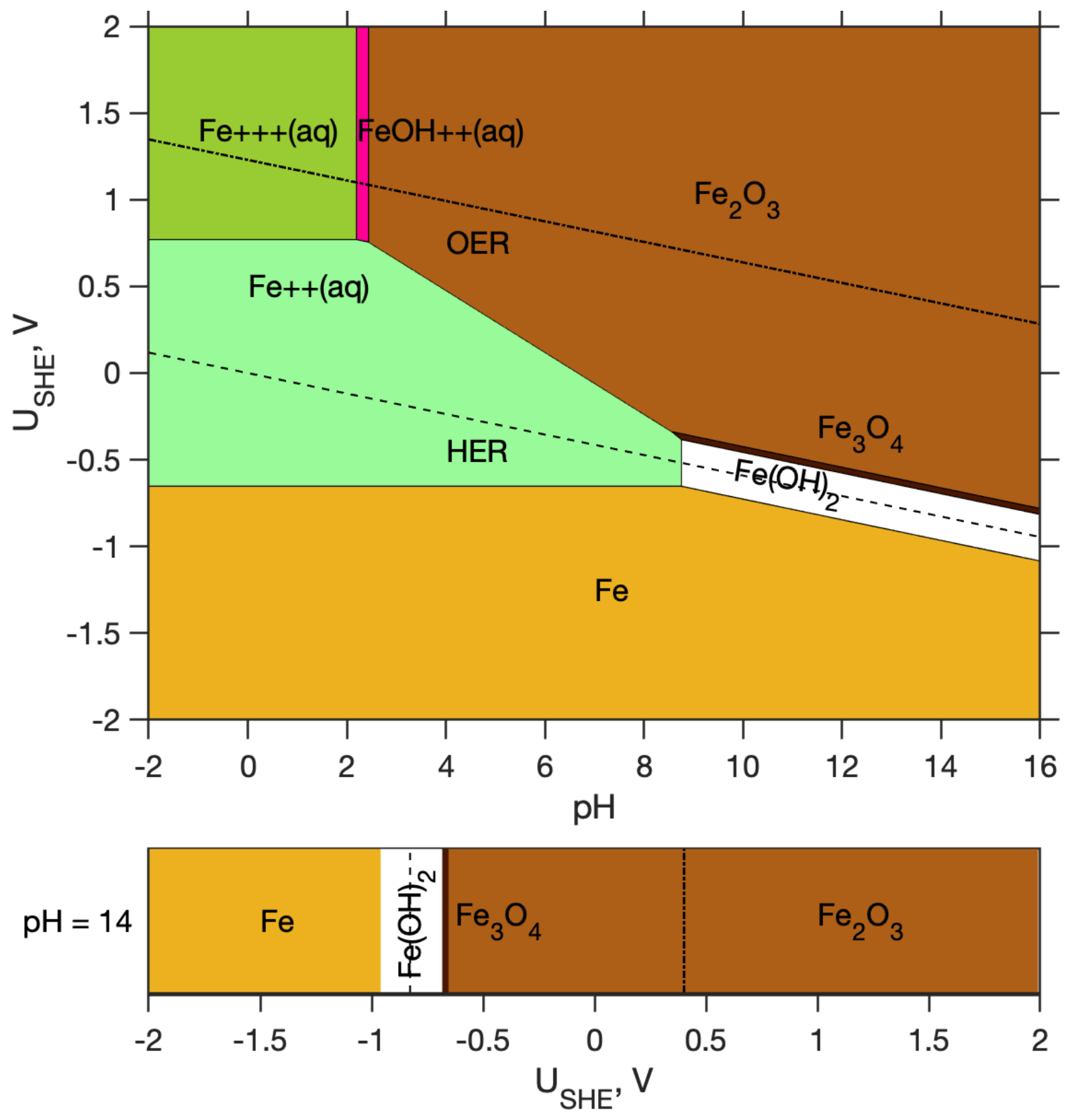

Figure 1: (a) Pourbaix diagram constructed based on the Free Energies listed in Table 1 and (b) Potential dependent phase transitions at $\mathrm{pH}=14$. 
Table 1: Free energies of Fe-O-H phases from the NIST Standard Reference Database $^{14}$

\begin{tabular}{|l|l|l|l|}
\hline Species & $\begin{array}{l}\Delta \mathrm{H}_{\mathrm{f}}^{\circ} \\
{[\mathrm{kJ} / \mathrm{mol}]}\end{array}$ & $\begin{array}{l}\mathrm{S}_{\mathrm{f}}^{\circ} \\
{[\mathrm{J} / \mathrm{mol} . \mathrm{K}]}\end{array}$ & $\begin{array}{l}\Delta \mathrm{G}_{\mathrm{f}}^{\circ} \\
{[\mathrm{kJ} / \mathrm{mol}]}\end{array}$ \\
\hline \hline $\mathrm{Fe}$ & 0 & 0 & 0 \\
\hline $\mathrm{Fe}(\mathrm{OH})_{2}$ & -574.04 & 87.93 & -600.24 \\
\hline $\mathrm{Fe}_{3} \mathrm{O}_{4}$ & -1120.89 & $\mathrm{u} / \mathrm{a}$ & -1120.89 \\
\hline $\mathrm{Fe}_{2} \mathrm{O}_{3}$ & -825.50 & $\mathrm{u} / \mathrm{a}$ & -825.50 \\
\hline $\mathrm{FeO}$ & -272.04 & 60.75 & -290.1 \\
\hline
\end{tabular}

by dissolution of the iron electrode. While reversible deposition and stripping could form the basis of a rechargeable iron electrode, we shift focus to the alkaline regime where there is potential for solid-solid phase transformations forming the basis for a rechargeable chemistry. The chemical transformations of the iron electrode under highly alkaline conditions are of interest. We show the stable phases of the electrode at $\mathrm{pH}=14$ in figure $1(\mathrm{~b})$. We note that until about $-0.95 \mathrm{~V}$ the stable form is pristine iron. Note that all potentials in this study are referenced to the standard hydrogen electrode (SHE). Ferrous hydroxide is associated with the lowest free energy in the potential window between $-0.95 \mathrm{~V}$ and $-0.68 \mathrm{~V}$. We observe a narrow window of stability for ferric oxide before transitioning to ferrous oxide as the stable phase above $-0.65 \mathrm{~V}$. The free energy variations of these phases as a function of the potential at $\mathrm{pH}=14$ is plotted in Figure $\mathrm{S} 1$ of the Supporting Information.

Overall, proposed sequence of transformation is Fe transforming to $\mathrm{Fe}(\mathrm{OH})_{2}$ then transforming to $\mathrm{Fe}_{3} \mathrm{O}_{4}$ and finally to $\mathrm{Fe}_{2} \mathrm{O}_{3}$. The competing hydrogen evolution reaction may limit the extent of oxidation and thus, in our analysis, we assume that reaction stops at $\mathrm{Fe}_{3} \mathrm{O}_{4}$ which involves $4 \mathrm{e}^{-}$transferred.

Electrolyte: As discussed previously, acidic media is not suitable for electrochemical discharge-charge energy storage operation of an iron electrode. Other studies ${ }^{15}$ note that alkaline electrolytes like $\mathrm{KOH}$ are not as corrosive to the iron electrode and further low solubility of the discharge products in alkaline media also prevents dendrite growth. ${ }^{15}$ Hence, 
the pragmatic choice of electrolyte is an alkaline aqueous electrolyte. We assume $1-6 \mathrm{M}$ $\mathrm{KOH}(\mathrm{pH}=14$ to 14.778$)$ as the electrolyte since several previous studies on iron-air systems have shown repeated cycling using such an electrolyte. ${ }^{16,17}$

Oxygen cathode: The reactions at the air electrode involve oxygen reduction and evolution, where several bi-functional catalyst options are available today. ${ }^{18}$ The oxygen reduction and evolution reactions are $\mathrm{O}_{2}+4 \mathrm{H}^{+}+4 \mathrm{e}^{-} \longleftrightarrow 2 \mathrm{H}_{2} \mathrm{O}$ and $4 \mathrm{OH}^{-} \longleftrightarrow \mathrm{O}_{2}+2 \mathrm{H}_{2} \mathrm{O}+4 \mathrm{e}^{-}$ respectively. ${ }^{19}$ It is worth highlighting that potential at which oxygen evolution occurs at $\mathrm{pH}=14$ (highly alkaline) is $0.404 \mathrm{~V}$ vs. SHE, as shown in figure 1 . We identify $\mathrm{MnO}_{2}$ and Ni-Fe layered double hydroxides to be a promising inexpensive platinum group metal-free bifunctional catalyst. Along similar lines, perovskites such as $\mathrm{La}_{0.6} \mathrm{Sr}_{0.4} \mathrm{Co}_{0.2} \mathrm{Fe}_{0.8} \mathrm{O}_{3}$ (LSCF), $\mathrm{LaSr}_{3} \mathrm{Fe}_{3} \mathrm{O}_{10}$ (LSFO) and $\mathrm{La}_{0.6} \mathrm{Ca}_{0.4} \mathrm{CoO}_{3}$ (LCCO) are alternative materials. ${ }^{15}$ Optimizing the catalyst cost and activity is critical to the techno-economics of the Fe-air system.

Iron-air cell working mechanism: For battery applications, the region between $-1.5 \mathrm{~V}$ to $0.5 \mathrm{~V}$ is of interest in an alkaline medium. ${ }^{20}$ The estimated discharge potential and the specific capacities of the three discharge products are shown in Table 2. During re-charge since HER is a competing reaction, we expect a significant reduction in charging efficiency which is considered a major drawback of the iron-air system. ${ }^{15,20}$ We assume the following discharge mechanism: discharge to $\mathrm{Fe}_{3} \mathrm{O}_{4}$ which provides a capacity of $\sim 828 \mathrm{mAh} / \mathrm{g}$ with an initial thermodynamic voltage of $1.36 \mathrm{~V}$ associated with $\mathrm{Fe}(\mathrm{OH})_{2}$ and a second step with $1.08 \mathrm{~V}$ associated with $\mathrm{Fe}_{3} \mathrm{O}_{4}$. A possible thrid step is the formation of $\mathrm{Fe}_{2} \mathrm{O}_{3}$ from $\mathrm{Fe}_{3} \mathrm{O}_{4}$ which has a associated discharge capacity of $\sim 335.7 \mathrm{mAh} / \mathrm{g}$ at a open circuit potential of $1.05 \mathrm{~V}$

Iron-air cell stack: The general cell stack design of an iron-air alkaline battery includes each metallic iron anode coupled with two air (oxygen) electrodes. The solid-phase discharge products are deposited on the anode surface and do not transport to the cathode side of the 
Table 2: Discharge capacities of the three possible discharge products and the equilibrium potential calculated from Table 1

\begin{tabular}{|l|l|l|}
\hline Species & $\begin{array}{l}\text { Capacity } \\
{[\mathrm{mAh} / \mathrm{g}]}\end{array}$ & $\begin{array}{l}\text { U, } \mathrm{pH}=14 \\
{[\mathrm{~V} \text { v. SHE }]}\end{array}$ \\
\hline \hline $\mathrm{Fe}(\mathrm{OH})_{2}$ & 596.61 & -0.96 \\
\hline $\mathrm{Fe}_{3} \mathrm{O}_{4}$ & 231.51 & -0.68 \\
\hline $\mathrm{Fe}_{2} \mathrm{O}_{3}$ & 335.67 & -0.66 \\
\hline \hline
\end{tabular}

system. The oxygen is generally supplied via a pneumatic driving force. Early designs of iron-air systems ${ }^{16}$ included considerations for expansion of iron electrodes during discharge and tuning the composition to mitigate hydrogen evolution during charging. The designs resulted in relatively thick $(>1 \mathrm{~mm})$ sintered electrodes. Studies show the most popular approach is to use powdered materials of iron or iron oxides supported by conductive materials. ${ }^{15}$ Mckerracher et al., ${ }^{15}$ identify three main considerations, (i) improving utilization, (ii) avoiding passivation, and (iii) reduction of hydrogen evolution-related inefficiency and parasitic reactions. In terms of the electrode composition, carbonyl iron-based electrodes do not use any support materials but $\mathrm{Fe}_{2} \mathrm{O}_{3}$ and $\mathrm{Fe}_{3} \mathrm{O}_{4}$ based materials use carbon and other support materials. ${ }^{15}$ Polymer-based separators are suggested in various studies, ${ }^{21}$ and for the cost and performance modeling, we assume a similar separator. The iron active material costs were derived from iron ore spot prices. $^{22}$

The air (oxygen) electrode assumptions are based on previous studies which modeled the performance and cost of air electrodes. ${ }^{9}$ The air electrode is assumed to be a porous electrode that has enhanced electronic conductivity via carbon-based materials, good ionic conductivity, and gas phase operation. We assume that a bi-functional catalyst based on $\mathrm{MnO}_{2}$ as discussed previously is used and that the ORR and OER reactions proceeding at the same exchange current density.

Oxygen delivery system is assumed to be an open iron-air architecture. The basic design is based on open Li-air architectures that have been previously modeled. ${ }^{9}$ The main components include compressors to generate the pressure drop, membrane units, and pressure-swing 
adsorption to separate oxygen from air. Previous studies have noted that the sizing and cost of such systems are not formalized, ${ }^{9}$ however, heuristics and expert analysis based estimates or $0.3 \mathrm{MPa} /$ stage compressors and related systems are available. ${ }^{9}$ We use these estimates to guide our assumptions while correcting for advantages of using aqueous electrolytes which do not require solvent addition or capture from the system unlike non-aqueous metal-air batteries. Further, given the much lower power operation of the iron-air long-duration storage system, the required operating air pressure would be much lower than lithium-air estimates form Gallagher et al. ${ }^{9}$

Cost estimation: The basic performance metrics of the Fe-air battery pack considered for the cost modeling are shown in Table 3. A lithium-air cost model developed by Gallagher et al., ${ }^{9}$ based on $\mathrm{BatPaC}^{8}$ was used as a foundation to construct a cost model for the iron-

air battery. All relevant material properties and performance estimates are appropriately modified for the iron-air system, and the .xlsx file for the model is made available. Several baseline manufacturing assumptions related to the battery manufacturing plant are retained. The baseline annual manufacturing capacity is 100,000 packs.

Table 3: Performance metrics of the baseline iron-air battery pack used to perform manufacturing cost estimation.

\begin{tabular}{|l|l|l|}
\hline Performance Metric & Value & Units \\
\hline \hline Designed pack energy & 110 & $\mathrm{kWh}$ \\
\hline Usable energy & 103 & $\mathrm{kWh}$ \\
\hline Designed power & 0.75 & $\mathrm{~kW}$ \\
\hline OCV at full charge & 1.36 & $\mathrm{~V}$ \\
\hline \hline
\end{tabular}

The five main categories that contribute to the total unit costs of an iron-air battery system are: (i) Cell materials and cell hardware, (ii) Battery pack with module hardware excluding the positive electrode active material i.e., air (oxygen), (iii) oxygen delivery system, (iv) pack integration i.e., battery management system, (v) manufacturing costs, overheads, administration, and other categories. 


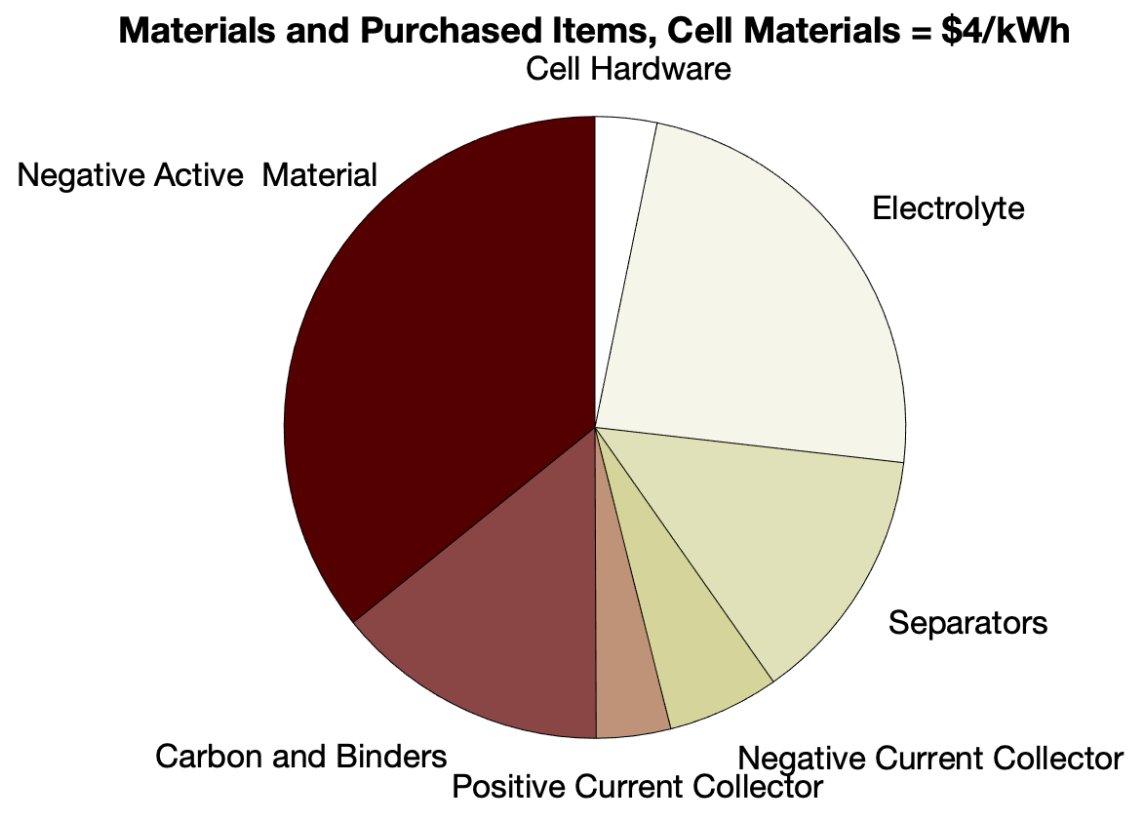

Materials and Purchased Items, Pack + Hardware $=\$ 12 / \mathbf{k W h}$

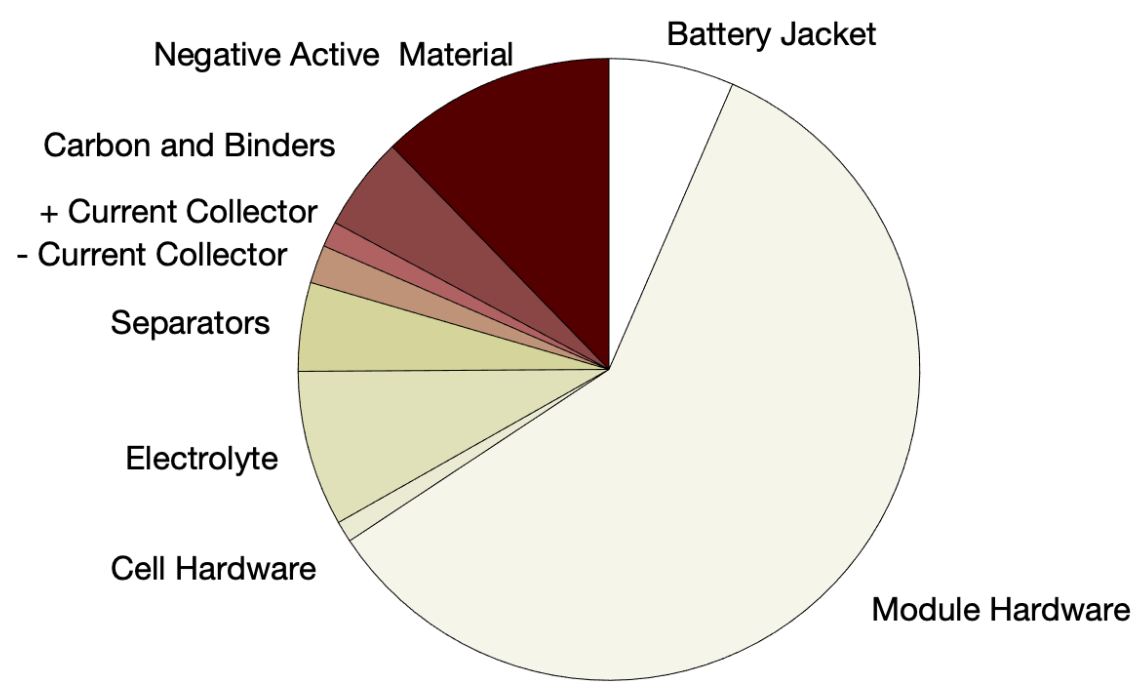

Figure 2: Materials and purchased materials cost breakdown for a iron-air battery pack (b) with and (a) without module hardware and battery jackets. 
Table 4: Cost of cell active and inactive raw materials, reported in the format for BatPaC-based cost modeling platform from Gallagher et al. ${ }^{9}$

\begin{tabular}{|l|l|}
\hline Component & Cost \\
\hline \hline Positive electrode & \\
Active material & $\mathrm{US} \$ 0.00 / \mathrm{kg}$ \\
Carbon & $\mathrm{US} \$ 3.00 / \mathrm{kg}$ \\
Binder PVDF & $\mathrm{US} \$ 5.00 / \mathrm{kg}$ \\
Binder Solvent (NMP) & $\mathrm{US} \$ 3.10 / \mathrm{kg}$ \\
\hline Negative electrode & \\
Active Material & $\mathrm{US} \$ 0.50 / \mathrm{kg}$ \\
Carbon Black & $\mathrm{US} \$ 3.00 / \mathrm{kg}$ \\
Binder & $\mathrm{US} \$ 5.00 / \mathrm{kg}$ \\
Binder Solvent & $\mathrm{US} \$ 0.00 / \mathrm{kg}$ \\
\hline Positive current collector & $\mathrm{US} \$ 0.30 / \mathrm{m}^{2}$ \\
Negative current collector & $\mathrm{US} \$ 0.50 / \mathrm{m}^{2}$ \\
Separators & $\mathrm{US} \$ 0.50 / \mathrm{m}^{2}$ \\
Electrolyte & $\mathrm{US} \$ 3.00 / \mathrm{L}$ \\
\hline
\end{tabular}

Categories (i) and (ii) are shown in Figure 2 where the cell material costs account for about US $\$ 4 / \mathrm{kWh}$ of battery pack and the addition of packing hardware brings it up to US $\$ 12 / \mathrm{kWh}$. It should be noted that the module hardware assumed here is similar to current Li-ion battery module hardware estimated to cost US\$1/cell and US\$0.005/Ah of capacity. The cost estimates for the iron-air module hardware are assumed to be lower than that of Li-ion given the voltage range of operation is smaller and that the battery pack is built with a priority to reduce total cost over hardware precision. The cost estimate for the module hardware represents an uncertainty of the developed model and should be explored in-depth in subsequent studies. As seen in Figure 2, the negative active material forms the largest fraction of the cell material cost which is about US $\$ 1.52 / \mathrm{kWh}$ out of the US $\$ 4 / \mathrm{kWh}$. The current collectors are assumed to be made of carbon or graphite-based materials instead of aluminum or copper used in previous lithium-air cost models. ${ }^{9}$ Aluminum or copper also have stability issues in alkaline conditions and would result in a significantly higher cost, and we find them unsuitable for use in low cost long-duration storage systems. A more detailed evaluation of the current collector choice is necessary and beyond the scope of the present 
study. Other details of the cost inputs used for the various cell materials and pack hardware can be found in the. $\mathrm{xlsx}$ model file available with the supporting information.

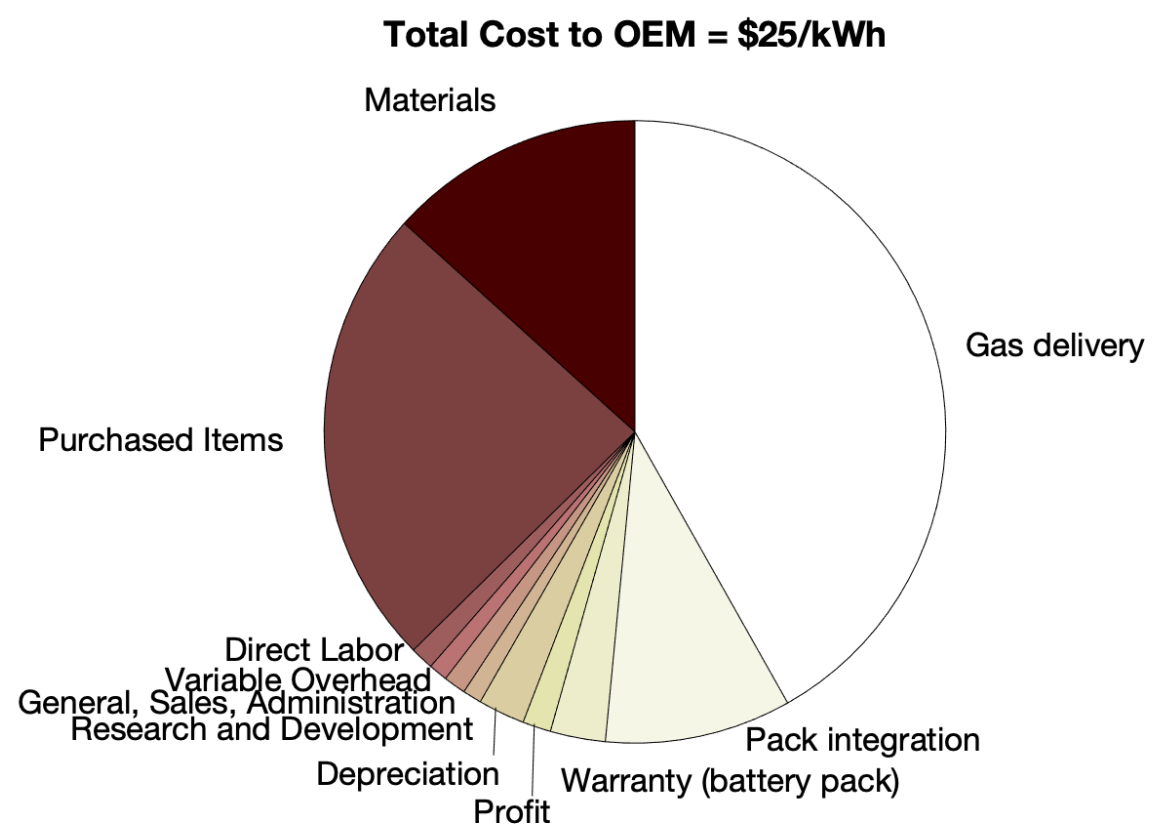

Figure 3: The total unit cost of an iron-air battery including the gas (air) delivery system, manufacturing costs and overheads.

The unit costs of a battery pack including the oxygen delivery system, system integration costs, manufacturing costs, overheads, and other costs can be seen in Figure 3. It can be seen that the oxygen delivery costs, marked under category (iii), alone is equivalent to the materials and purchased items cost at about US $\$ 6.3 / \mathrm{kWh}$. We find that there is room for engineering innovation here to drive the gas delivery costs associated with compressors, PSA beds, and other related systems which can have a significant impact on the unit costs of the battery pack system. Category (iv) on pack integration which includes the battery management system and related hardware which accounts for about US $\$ 3.25 / \mathrm{kWh}$. We do not use an active thermal management system given elevated temperatures are found to be beneficial for the operation of an iron-air battery, ${ }^{16}$ and given that the system is designed for stationary storage applications. Along with other manufacturing costs and overheads, the total cost of the iron-air system is estimated to be about US $\$ 25 / \mathrm{kWh}$ where the material 
costs of the battery pack is about US $\$ 12 / \mathrm{kWh}$ and that of the cell alone excluding the pack hardware is about US\$4/kWh. The choice of catalysts for the air electrode moves these estimates between US\$1-\$3/kWh and relevant estimates can be found in the .xlsx model file in the supporting information.

Table 5: Battery pack cost estimates for iron-air compared to lithium-ion batteries.

\begin{tabular}{|l|l|l|l|l|l|}
\hline Iron-air & LFP & NMC811 & NMC622 & NCA & Stationary Storage \\
\hline & EV & EV & EV & EV & (across chemistries) \\
US\$ $/ \mathrm{kWh}$ & $\mathrm{US} \$ / \mathrm{kWh}$ & $\mathrm{US} \$ / \mathrm{kWh}$ & $\mathrm{US} \$ / \mathrm{kWh}$ & $\mathrm{US} \$ / \mathrm{kWh}$ & $\mathrm{US} \$ / \mathrm{kWh}$ \\
\hline \hline 25 & $97^{23}$ & $141^{23}$ & $143^{23}$ & $120^{6}$ & $137^{6}$ \\
\hline \hline
\end{tabular}

Comparison with other existing energy storage technologies: The the cost of the iron-air battery pack system at US $\$ 25 / \mathrm{kWh}$ is considerably lower cost compared to lithiumion batteries which are generally designed for portable energy storage applications. Current estimates for the cost of lithium-ion for EV and stationary storage applications are shown in Table 5.

Potential for long-duration iron-air storage batteries: Recent studies ${ }^{24}$ on the long duration energy storage systems capable of addressing intermittency in renewable energy generation should have a system cost $\leq \mathrm{US} \$ 20 / \mathrm{kWh}$, while also noting that charge efficiency plays a secondary role. The iron-air system shows considerable promise in this context with the material costs of about US $\$ 4 / \mathrm{kWh}$ and total system cost US $\$ 25 / \mathrm{kWh}$ with room for improvements in terms of engineering the hardware and gas delivery systems to further drive costs down. Cheaper bi-functional catalysts for the oxygen electrode can modify the cost substantially, currently accounting for about $10 \%$ of the cost of the system and the roundtrip efficiency. Thus, optimizing the bi-functional catalyst to improve the oxygen reduction (discharge) overpotential can lead to improvements, leading to about $10 \%$ increase in discharge efficiency, thereby leading to another $10 \%$ reduction in cost. If additional capacity 
from the system via transition of $\mathrm{Fe}_{3} \mathrm{O}_{4}$ to $\mathrm{Fe}_{2} \mathrm{O}_{3}$ could be accomplished, this will lead to an increase in capacity of about $\sim 335 \mathrm{mAh} / \mathrm{g}$. This will lead to $\sim 40 \%$ increase in capacity and can lead to further cost reductions.

Summary: In this work, we have performed a first-principles techno-economic analysis of the iron-air system. Based on this analysis, we find several key drivers that determine the cost of the battery pack system: (i) Gas (air) delivery systems cost and (ii) system hardware costs including module hardware and BMS, while the cell materials costs account for about a fifth of the total battery pack costs. The analysis represent a first-step towards understanding the techno-economics of the iron-air system and has substantial uncertainty for several subsystems. We have made the entire model available and we hope that this will spur further analysis on these subsystems. A few subsystems that require further investigation involve the choice of cheap and stable current collectors in the operating regime, bifunctional catalyst performance-and-cost and module hardware.

Data and Model Availability: The .xlsx model file and other can is hosted at https: //github.com/BattModels/fe-air

Author Contributions: V.V. performed Pourbaix analysis and the mechanism of operation with input from D.K. and S.S.. S.S. performed the cost analysis and identifying the underlying parametric inputs for the techno-economic model. All authors jointly discussed the results and wrote the paper.

Competing Interests: V.V. is a technical consultant and Scientific Advisory Board member at QuantumScape Corporation, Chief Scientist at Aionics, and technical consultant to Form Energy. All analysis carried out in this work is independent work of the authors.

\section{References}

(1) Davis, S. J.; Lewis, N. S.; Shaner, M.; Aggarwal, S.; Arent, D.; Azevedo, I. L.; Benson, S. M.; Bradley, T.; Brouwer, J.; Chiang, Y.-M. et al. Net-zero emissions energy 
systems. Science 2018, 360 .

(2) Li, Z.; Pan, M. S.; Su, L.; Tsai, P.-C.; Badel, A. F.; Valle, J. M.; Eiler, S. L.; Xiang, K.; Brushett, F. R.; Chiang, Y.-M. Air-breathing aqueous sulfur flow battery for ultralowcost long-duration electrical storage. Joule 2017, 1, 306-327.

(3) LeVine, S. Big Automakers Are Underplaying Surprising News: LFP Batteries Are Back. 2021; https://themobilist.medium.com/ big-automakers-are-underplaying-surprising-news-lfp-batteries-are-back-483553a11328

(4) Form Energy Inc., BATTERY TECHNOLOGY. 2021; https://formenergy.com/ technology/battery-technology/.

(5) Friesen, C. A. 2021; https://twitter.com/CodyAFriesen/status/ 1418269949760577545.

(6) Bloomberg New Energy Finance, 2020 Lithium-Ion Battery Price Survey; 2020.

(7) Yang, X.-G.; Liu, T.; Wang, C.-Y. Thermally modulated lithium iron phosphate batteries for mass-market electric vehicles. Nature Energy 2021, 6, 176-185.

(8) Nelson, P. A.; Gallagher, K.; Bloom, I. BatPaC (battery performance and cost) software. Argonne National Laboratory 2012,

(9) Gallagher, K. G.; Goebel, S.; Greszler, T.; Mathias, M.; Oelerich, W.; Eroglu, D.; Srinivasan, V. Quantifying the promise of lithium-air batteries for electric vehicles. Energy Environ. Sci. 2014, 7, 1555-1563, Publisher: The Royal Society of Chemistry.

(10) Vinogradova, O.; Krishnamurthy, D.; Pande, V.; Viswanathan, V. Quantifying confidence in DFT-predicted surface pourbaix diagrams of transition-metal electrodeelectrolyte interfaces. Langmuir 2018, 34, 12259-12269. 
(11) Sumaria, V.; Krishnamurthy, D.; Viswanathan, V. Quantifying confidence in DFT predicted surface pourbaix diagrams and associated reaction pathways for chlorine evolution. ACS Catalysis 2018, 8, 9034-9042.

(12) Machala, L.; Tucek, J.; Zboril, R. Polymorphous transformations of nanometric iron (III) oxide: a review. Chemistry of Materials 2011, 23, 3255-3272.

(13) Nørskov, J. K.; Rossmeisl, J.; Logadottir, A.; Lindqvist, L.; Kitchin, J. R.; Bligaard, T.; Jonsson, H. Origin of the overpotential for oxygen reduction at a fuel-cell cathode. The Journal of Physical Chemistry B 2004, 108, 17886-17892.

(14) Daniel Siderius, NIST Standard Reference Simulation Website - SRD 173. 2017; https: //data.nist.gov/od/id/FF429BC178798B3EE0431A570681E858232.

(15) McKerracher, R. D.; Ponce de Leon, C.; Wills, R. G. A.; Shah, A. A.; Walsh, F. C. A Review of the Iron-Air Secondary Battery for Energy Storage. ChemPlusChem 2015, 80, 323-335, _eprint: https://chemistryeurope.onlinelibrary.wiley.com/doi/pdf/10.1002/cplu.201402238.

(16) Öjefors, L.; Carlsson, L. An iron - air vehicle battery. Journal of Power Sources 1978, 2, 287-296.

(17) Vijayamohanan, K.; Shukla, A. K.; Sathyanarayana, S. Kinetics of electrode reactions occurring on porous iron electrodes in alkaline media. Journal of Electroanalytical Chemistry and Interfacial Electrochemistry 1990, 295, 59-70.

(18) Ibrahim, K. B.; Tsai, M.-C.; Chala, S. A.; Berihun, M. K.; Kahsay, A. W.; Berhe, T. A.; $\mathrm{Su}$, W.-N.; Hwang, B.-J. A review of transition metal-based bifunctional oxygen electrocatalysts. Journal of the Chinese Chemical Society 2019, 66, 829-865.

(19) Krishnamurthy, D.; Sumaria, V.; Viswanathan, V. Maximal predictability approach for 
identifying the right descriptors for electrocatalytic reactions. The journal of physical chemistry letters 2018, 9, 588-595.

(20) Vijayamohanan, K.; Balasubramanian, T. S.; Shukla, A. K. Rechargeable alkaline iron electrodes. Journal of Power Sources 1991, 34, 269-285.

(21) Yensen, N.; Allen, P. B. Open source all-iron battery for renewable energy storage. HardwareX 2019, 6, e00072.

(22) Markets Insider, IRON ORE, Commodity Price. 2021; https://markets . businessinsider.com/commodities/iron-ore-price.

(23) Frith, J. T. 2021; https://twitter.com/JamesTFrith/status/ 1423648744956997633.

(24) Sepulveda, N. A.; Jenkins, J. D.; Edington, A.; Mallapragada, D. S.; Lester, R. K. The design space for long-duration energy storage in decarbonized power systems. Nature Energy 2021, 6, 506-516. 